\section{Estimation of genetic parameters and selection for rooting capacity in peach}

\author{
João Alison Alves Oliveira ${ }^{1 *}$, Cláudio Horst Bruckner ${ }^{1}$, Danielle \\ Fabíola Pereira da Silva ${ }^{2}$, Carlos Eduardo Magalhães dos \\ Santos ${ }^{1}$, Gener Augusto Penso ${ }^{1}$ and César Fernandes Aquino ${ }^{3}$
}

\begin{abstract}
One of the most important criteria in the improvement of rootstocks is easiness of propagation. The objective of the present study was to verify the existence of genetic variability and the possibility of gains with selection in the rooting capacity among peach genotypes. Seventy-seven genotypes of peach belonging to five $F_{3}$ families were evaluated. Rooting percentage $(R P)$, number of roots per cutting (NR) and mean root length ( $R L)$ were evaluated. Genetic values were estimated. The nineteen genotypes with the lowest rank summation index were selected to estimate the genetic gains. The variables RP, NR and $R L$ had progeny mean heritabilities of $0.53,0.60$ and 0.83 , respectively. Of the individuals selected, $89.5 \%$ belonged to the 713 (Talismã $x$ Adafuel) family. The estimation of the genetic and phenotypic parameters show the possibility of success by selecting superior genotypes, with gains of 9.09, 17.47 and $24 \%$ for $R P, N R$ and $R L$, respectively.
\end{abstract}

Key words: Prunus persica, Rootstock, REML/BLUP, Selection index, Cuttings.

\section{INTRODUCTION}

The propagation of peach trees in Brazil is still based on grafting on rootstock seedlings derived from seeds obtained as by-products of fruit-processing industry, mainly in the South of the Country. This type of plant material results in rootstocks without guarantee of genetic identity, causing non-uniformity in clonal orchards and different reactions of plants to soil pathogens and abiotic stresses (Fachinello et al. 2005, Picolotto et al. 2010). For many years, the peach breeding programs in Brazil have aimed to improving scion cultivars and overlooked the improvement of rootstocks.

Different studies with Prunus spp. (Forcada et al. 2012, Mestre et al. 2015, Reig et al. 2016) revealed that the rootstock influences the agronomic performance (tree vigour, yield efficiency, water relations, leaf gas exchange, mineral nutrients uptake, plant size, bloom and harvest dates, and fruit bud survival). The rootstock choice represents one of the most important considerations for a productive peach orchard.

To help to address these research gaps, the Federal University of Viçosa has been conducting a genetic improvement program for peach rootstocks, hoping to obtain new high-performance rootstock cultivars adapted to the growing region and with good interaction with the scion cultivars.
Crop Breeding and Applied Biotechnology 18: 320-324, 2018 Brazilian Society of Plant Breeding. Printed in Brazil http://dx.doi.org/10.1590/1984$70332018 v 18 n 3 n 47$ \section{政}


The use of genetically improved rootstocks demands changes in the propagation system. Vegetative propagation maintains a genetic identity of selected rootstocks, while seed propagation generates segregation and consequently non-uniformity. Research to improve the system of obtaining peach rootstocks have been carried out (Bruckner and Dejong 2014, Forcada et al. 2012), as well as using vegetative propagation by cutting as an alternative (Mayer et al. 2014).

Thus, the objective of the present study was to verify the existence of genetic variability and the possibility of gains with selection in the rooting capacity among peach genotypes.

\section{MATERIAL AND METHODS}

The experiment was conducted from November to December 2015, in an intermittent mist chamber at the Agricultural Department of the Federal University of Viçosa (lat $20^{\circ} 45^{\prime} 26^{\prime \prime} \mathrm{S}$, long $42^{\circ} 52^{\prime} 08^{\prime \prime} \mathrm{W}$ and alt $638 \mathrm{~m}$ asl).

Softwood cuttings of 77 individuals from five peach families at the $F_{3}$ generation $\left(S_{2}\right)$ belonging to the UFV Genetic Improvement Program were collected at the beginning of November (Table 1). The cuttings were standardized with a length of $15 \mathrm{~cm}$, with a pair of leaves, cut straight at the

Table 1. Peach families, genealogy and number of individuals evaluated for selection of rootstock genotypes for rooting capacity.

\begin{tabular}{lcc}
\hline \multirow{2}{*}{ Family } & $\begin{array}{c}\text { Number of individuals } \\
\text { per family }\end{array}$ & \multicolumn{2}{c}{ Parent } \\
\cline { 3 - 3 } & 20 & Relíquia x Diamante \\
713 & 23 & Talismã x Adafuel \\
713 & 12 & Okinawa x GN9 \\
913 & 20 & Real x Premier \\
1013 & 2 & Okinawa x GN22 \\
1113 &
\end{tabular}
base and the apex cut just above an auxiliary bud. Then, two opposite lesions $( \pm 3 \mathrm{~cm}$ ) were cut at the base of the cutting to expose the vascular cambium.

The basal ends of cuttings were dipped into a hydro-alcoholic solution with a concentration of $3000 \mathrm{mg} \mathrm{L}^{-1}$ IBA for 5 seconds. The cuttings were then placed in $(36.5 \times 26.5 \times 9.5 \mathrm{~cm})$ perforated plastic trays containing sand, at 4 to $5 \mathrm{~cm}$ depth. The boxes were kept under intermittent mist spraying programmed for every 3.5 minutes for 5 seconds, only operating in daytime. The greenhouse is covered with polyethylene film and sides with anti-aphid screen.

The experiment was arranged in a completely randomized design, with five replications and each plot consisted of eight cuttings. After 46 days of the experiment installation, the following traits were evaluated: rooted cuttings (\% of cuttings with at least one root) (RP); number of roots per cutting (only roots that originated directly from the cutting) $(\mathrm{NR})$; mean length of five roots $(\mathrm{cm})(\mathrm{RL})$.

Data were analyzed using the methodology of mixed linear models. The estimation of the genetic parameters was performed by REML (Restricted Maximum Likelihood) and genotypic values were estimated by the BLUP method (best non-biased linear predictor) using the Selegen REML/BLUP software (Resende 2016). The statistical model adopted was: $y=X r+Z g+W p+e$, where $y$ is the data vector, $r$ is the vector of the repetition effects (assumed as fixed) added to the general mean, $g$ is the vector of the additive genetic effects (assumed as random), $p$ is the vector of the plot effects and $\mathrm{e}$ is the vector of errors (random); The capital letters (X, Z and W) represent the incidence matrices for the said effects.

The REML/BLUP method ranked the individuals according to the predicted genotypic values found for each trait. From these values, the selection was applied based on the Mulamba and Mock (1978) index. This index consists of classifying the individuals, in relation to each trait, in an order that favors improvement. The orders referring to the traits are summed for each genotype, obtaining the sum of ranks. Thus, the lower the value obtained in the sum of ranks, the better the performance of the genotype, in relation to the different traits evaluated (Cruz et al. 2012). The 19 genotypes (25\%) with the lowest value of the sum of ranks were selected, and the selection gain was estimated by the equation $G_{s}=\left(\bar{X}_{s}-\bar{X}_{0}\right) h^{2}$ where: GS is the selection gain; $\bar{X}_{s}$ is the mean of the 19 selected genotypes; $\bar{X}_{0}$ is the mean of the 77 genotypes evaluated and $\mathrm{h}^{2}$ is the individual broad-sense heritability.

\section{RESULTS AND DISCUSSIONS}

Rooting percentage had the highest genotypic variance $\left(\sigma_{\mathrm{g}}^{2}\right)$, which was 127.5 (Table 2 ), indicating a favorable condition to the genetic improvement program of peach rootstock, enabling the identification of superior genotypes. Falconer \& Mackay (1996) points out that the existence of genetic variation in the population is a basic condition for obtaining gains from selection. 
Estimates of individual broad-sense heritability $\left(h^{2}\right)$ were considered moderate, ranging from $0.15(\mathrm{RP})$ to 0.42 (RL) (Table 2), according to Resende (2007), who considered heritability of low magnitude when $h^{2}<0.15$, medium magnitude when $0.15<h^{2}>0.50$, and high magnitude when $h^{2}>0.50$. The magnitude of the heritability obtained shows that a moderate genetic control can be obtained, which ensures that the selection, at individual and progeny levels, would provide significant gains for the trait. Varago et al. (2017) discuss that the individual heritability of $51.4 \%$ found in the selection of peach genotypes for resistance to bacterial leaf spot (Xanthomonas arboricola pv. pruni) implies the existence of genetic variability in the studied progeny, enabling us to infer that selection may be effective for obtaining genetic gains for the evaluated characteristic.

The estimates of progeny-mean heritability $\left(\mathrm{h}^{2}{ }_{\mathrm{mp}}\right)$ for $R P, N R$, and $R L$ were of high magnitude: $0.53,0.60$, and 0.83 , respectively (Table 2 ), and were superior to those obtained by the individual heritability, showing that, in this case, the selection may be more effective and indicating a greater prospect of genetic gain. Falconer \& Mackay (1996) describes heritability as a property not only of a trait but also of the population and the environmental conditions to which individuals are subjected.Therefore, its value may be affected if there is a change in any of the components of the genetic and phenotypic variances.

The coefficient of determination of plot effects $\left(\mathrm{C}^{2}{ }_{\text {plot }}\right)$ was considered low for the traits evaluated, 0.09, 0.09, and 0.06 for RP, NR and RL, respectively, indicating the presence of a small environmental variation within the plots, that is, the effect of plots was small.

The estimate of the individual genotypic variation coefficient $\left(\mathrm{CV}_{\mathrm{gi}}\right)$, expresses the amount of genetic variation that exists. Expressive values were observed for the traits studied, ranging from 25.86 (RP) to 41.56 (NR). This result indicates that populations are susceptible to genetic progress by continuing selection cycles. Maia et al. (2009) argues that with values of this magnitude, it is possible to obtain success with the selection of genotypes and considerable gains.

In general, the coefficient of residual variation $\left(\mathrm{CV}_{\mathrm{e}}\right)$ values obtained were from low to medium, ranging from 17.09 (RL) to 33.64 (NR), remaining at acceptable levels for the experimentation. However, the $\mathrm{CV}_{\mathrm{e}}$ is little informative, thus the analysis and interpretation of the accuracy estimate is more important (Resende and Duarte 2007).

The relative coefficient of variation $\left(\mathrm{CV}_{\mathrm{r}}\right)$, equivalent to the variation index, refers to the magnitude of the $\mathrm{CV}_{\mathrm{g}} / \mathrm{CV}_{\mathrm{e}}$ ratio, and according to Resende and Duarte (2007), CVr values equal to 1.0 are adequate for providing high-accuracy and highprecision inferences. The present study found $\mathrm{CV}_{r}$ values between 1.06 (RP) and 2.21 (RL) (Table 2), showing that there is a possibility of success with progeny selection, since this parameter indicates that the genetic variation between the
Table 2. Estimates of genetic parameters for the traits percentage of rooting cuttings (RP), number of roots per cutting (NR), and mean length of roots in $\mathrm{cm}(\mathrm{RL})$

\begin{tabular}{lccc}
\hline \multirow{2}{*}{ Parameter } & \multicolumn{3}{c}{ Trait } \\
\cline { 2 - 4 } & $\mathbf{R P}$ & $\mathbf{N R}$ & $\mathbf{R L}$ \\
\hline$\sigma_{\mathrm{g}}{ }^{*}$ & 127.47 & 4.44 & 2.48 \\
$\mathrm{~h}^{2}$ & 0.15 & 0.19 & 0.42 \\
$\mathrm{C}^{2}{ }_{\text {plot }}$ & 0.09 & 0.09 & 0.06 \\
$\mathrm{~h}^{2}{ }_{\mathrm{mp}}$ & 0.53 & 0.60 & 0.83 \\
$\mathrm{Acs}$ & 0.73 & 0.78 & 0.91 \\
$\mathrm{CV}_{\mathrm{gi}}(\%)$ & 25.86 & 41.56 & 37.81 \\
$\mathrm{CV}_{\mathrm{e}}(\%)$ & 24.26 & 33.64 & 17.09 \\
$\mathrm{CV}_{\mathrm{r}}$ & 1.06 & 1.23 & 2.21 \\
Overall mean & 43.66 & 5.07 & 4.17 \\
\hline
\end{tabular}

${ }^{*} \sigma^{2}$ : genetic variance among progenies; $\mathrm{h}^{2}$ : individual broad-sense heritability among families, equivalent to narrow-sense heritability, since ignoring the fraction (1/4) of the dominance genetic variance; $C^{2}$ plot: coefficient of determination of plot effects; $h^{2} \mathrm{mp}$ : progeny mean heritability; Acs: accuracy of progeny selection; CVgi\%: coefficient of individual additive genetic variation; $\mathrm{CVe} \%$ : coefficient of residual variation; $\mathrm{CV}$ r: relative coefficient of variation (CVgi/CVe).

Table 3. Peach individuals selected (at $25 \%$ intensity) by the Mulamba and Mock (1978) index and their respective genetic values for the variables rooting percentage (RP), number of roots per cutting (NR) and mean root length in $\mathrm{cm}(\mathrm{RL})$

\begin{tabular}{|c|c|c|c|c|}
\hline \multirow{2}{*}{ Individual } & $\mathbf{R P}$ & NR & $\mathbf{R L}$ & \multirow{2}{*}{ Index } \\
\hline & \multicolumn{3}{|c|}{ Genetic value $(u+a)$} & \\
\hline $613-2$ & 48.99 & 5.81 & 6.51 & 60 \\
\hline $613-17$ & 49.23 & 6.43 & 6.77 & 60 \\
\hline $713-2$ & 55.10 & 7.16 & 5.70 & 44 \\
\hline $713-3$ & 52.95 & 7.29 & 5.67 & 49 \\
\hline $713-4$ & 55.58 & 7.70 & 6.12 & 23 \\
\hline $713-5$ & 58.45 & 8.75 & 5.60 & 28 \\
\hline $713-7$ & 58.45 & 8.27 & 6.10 & 16 \\
\hline $713-8$ & 54.86 & 7.44 & 5.75 & 38 \\
\hline $713-9$ & 53.58 & 7.19 & 5.09 & 62 \\
\hline $713-10$ & 54.46 & 7.08 & 5.61 & 52 \\
\hline $713-14$ & 51.51 & 6.65 & 6.00 & 52 \\
\hline $713-15$ & 55.34 & 7.42 & 5.37 & 51 \\
\hline $713-17$ & 54.14 & 6.81 & 5.65 & 57 \\
\hline $713-18$ & 56.53 & 7.67 & 5.71 & 34 \\
\hline $713-19$ & 57.97 & 7.81 & 6.78 & 12 \\
\hline $713-20$ & 57.25 & 7.73 & 5.77 & 25 \\
\hline $713-21$ & 58.45 & 8.62 & 5.64 & 29 \\
\hline $713-22$ & 58.69 & 8.41 & 6.84 & 5 \\
\hline $713-23$ & 57.25 & 7.66 & 5.76 & 31 \\
\hline
\end{tabular}


progenies is much higher than the environmental variation.

In the genotypic evaluation, accuracy (Acs) is also an important statistical parameter because it refers to the correlation between the predicted genetic values and the true genetic values of the individuals and is linked to trait heritability (Resende and Duarte 2007). The accuracy ranged from $0.73(\mathrm{RP})$ to 0.91 (RL), which were considered values of high precision. Thus, the high experimental rigor of the present study and the reliability in the selection of genotypes for the traits related to rooting capacity stand out in this experiment.

Among the top $25 \%$ individuals (19 genotypes) based on the Mulamba and Mock (1978) index, aiming to increase rooting percentage, root numbers and root mean length (Table 3), only families 613 (2 genotypes) and 713 (17 genotypes) had individuals selected. One possible explanation for the best result obtained by the family 713 is its genealogy (Table 1). One of its parents was the rootstock 'Adafuel', a hybrid between almond and peach selected by ESAD-CSIC (Zaragoza, Spain), and according to Reighard and Loreti (2008), it is easily propagated by cuttings and extremely vigorous and compatible with most peach cultivars.

The index based on genotypic values was consistent in ranking individuals based on all traits evaluated; it is therefore suitable to be used as a strategy in the selection of superior genetic material. Resende (2007) states that the REML/BLUP methodology puts the potential genotypes into an order for selection, exploring all the genotype variation among and within progenies, however, considering each trait analyzed separately. This procedure has been shown to be efficient, for passion fruit (Freitas et al. 2016, Santos et al. 2015), guava (Paiva et al. 2016), and papaya (Oliveira et al. 2012, Vivas et al. 2014).

The selection of the 19 genotypes provided direct predicted gains of $9.09 \%$ for rooting percentage, $17.47 \%$ for number of roots per cutting, and $24.0 \%$ for mean root length (Table 4). The selection of these genotypes in this selection cycle promoted high genetic gains; however, the recombination of the selected genotypes could lead to a reduction of the gains, in the next selection cycles, due to the probable process of inbreeding. One of the most important criteria in the improvement of rootstocks is easiness of propagation since farmers will require rapid availability of the new rootstock cultivar. Thus, the use of genetically improved rootstocks requires modification of the propagation system, with the vegetative propagation by cuttings being the most recommended, as it preserves the genetic identity of the selected rootstocks (Bruckner and Dejong 2014, Reighard and Loreti 2008).

\section{CONCLUSIONS}

The estimates of the genetic parameters reveal the existence of genetic variability and selective potential among the studied peach genotypes.

The Mulamba and Mock selection index provides positive genetic gains in the rooting percentage, root number and mean root length.

\section{ACKNOWLEDGEMENTS}

The authors thank CNPq, CAPES and FAPEMIG for the financial support.

\section{REFERENCES}

Brucnker CH and Dejong TM (2014) Proposed pre-selection method for identification of dwarfing peach rootstocks based on rapid shoot xylem vessel analysis. Scientia Horticulturae 165: 404-409.

Cruz CD, Regazzi AJ and Carneiro PCS (2012) Modelos biométricos aplicados ao melhoramento genético. Editora UFV, Viçosa, 514p.

Falconer DS and Mackay TFC (1996) Introduction to quantitative genetics. 4.ed. : Longman Group Limited, Edinburgh, 464p. Forcada CF, Gogorcena $Y$ and Moreno MA (2012) Agronomical and fruit quality traits of two peach cultivars on peach-almond hybrid rootstocks growing on Mediterranean conditions. Scientia Horticulturae 140: 
$157-163$

Freitas JCO, Viana AP, Santos EA, Paiva CL, Silva FH and Souza MM (2016) Sour passion fruit breeding: Strategy applied to individual selection insegregating population of Passiflora resistant to Cowpea aphidbornmosaic virus (CABMV). Scientia Horticulturae 211: 241-247.

Fachinello JC, Hoffmann A and Nachtigal JC (2005) Propagação de plantas frutíferas. Embrapa Informações Tecnológicas, Brasília, 221p.

Maia MCC, Resende MDV, Paiva JR, Cavalcanti JJV and Barros LMB (2009) Seleção simultânea para produção, adaptabilidade e estabilidade genotípicas em clones de cajueiro, via modelos mistos. Pesquisa Agropecuária Tropical 39: 43-50.

Mayer NA, Picolotto L, Bastos PV, Ueno B. and Antunes LEC (2014) Estaquia herbácea de porta-enxertos de pessegueiro no final do verão. Semina 35: 1761-1771.

Mestre L, Reig G, Betrán JA, Pinochet J and Ángeles MA (2015) Influence of peach - almond hybrids and plum-based rootstocks on mineral nutrition and yield characteristics of 'Big Top' nectarine in replant and heavy-calcareous soil conditions. Scientia Horticulturae 192: 475-481.

Mulamba NN and Mock JJ (1978) Improvement of yield potential of the Eto Blanco maize (Zea mays L.) population by breeding for plant traits. Egyptian Journal Genetics and Cytology 7: 40-51.

Oliveira EJ, Fraife-Filho GA, Freitas JPX, Dantas JLL and Resende MDV (2012) Plant selection in F2 segregating populations of papaya from comercial hybrids. Crop Breeding and applied Biotechnology 12: 191-198.

Paiva CL, Viana AP, Santos EA, Freitas JSO and Amaral Junior AT (2016) Genetic gain estimated by diferent selection criteria in guava progenies. Bragantia 75: 418-427.
Picolotto L, Fachinello JC, Bianchi VJ, Manica-Berto R, Pasa MS and Schmitz JD (2010) Yield and fruit quality of peach scion by using rootstocks propagated by air layering and seed. Scientia Agricola 67: 646-650.

Reig G, Mestre L, Betrán JA, Pinochet J and Moreno MA (2016) Agronomic and physicochemical fruit properties of 'Big Top' nectarine budded on peach and plum based rootstocks in Mediterranean conditions. Scientia Horticulturae 210: 85-92.

Reighard GL and Loreti F (2008) Rootstock development. In Layne DR and Bassi D (eds) The peach: botany, production and uses. CABI North American Office, Oxfordshire, p. 193-220.

Resende MDV and Duarte JB (2007) Precisão e controle de qualidade em experimentos de avaliação de cultivares. Pesquisa Agropecuária Tropical 37: 182-194.

Resende MDV (2007) Matemática e estatística na análise de experimentos e no melhoramento genético. Embrapa Florestas, Colombo, 362p.

Resende MDV (2016) Software Selegen-REML/BLUP: a useful tool for plant breeding. Crop Breeding and Applied Biotechnology 15: 330-339.

Santos EA, Viana AP, Freitas JCO, Rodrigues DL, Ferreira RT, Paiva CL and Souza MM (2015) Genotype selection by REML/BLUP methodology in a segregating population from an interspecific Passiflora spp crossing. Euphytica 204: 1-11.

Varago AL, Citadin I, Sachet MR, Penso GA and Raseira MCB (2017) Herdability of peach tree resistance to bacterial leaf spot. Pesquisa Agropecuária Brasileira 52: 366-369.

Vivas M, Silveira SF, Vivas JMS, Viana AP, Amaral Junior AT and Pereira MG (2014) Seleção de progênies femininas de mamoeiro para resistência a mancha-de-phoma via modelos mistos. Bragantia 73: 446-450.

(cc) EY This is an Open Access article distributed under the terms of the Creative Commons Attribution License, which permits unrestricted use, distribution, and reproduction in any medium, provided the original work is properly cited. 